УДК 93/94 История

DOI: $10.21779 / 2542-0313-2019-34-2-14-20$

\title{
М.Т. Гаджимурадов
}

\section{Феодальная война в Южном Дагестане во второй половине XVIII в.}

Дагестанский государственный университет; Россия, 367001, 2. Махачкала, ул. М. Гаджиева, 43a; murad-docent@mail.ru

Статья посвящена феодальным междоусобным войнам в Дагестане во второй половине XVIII в. Проанализированы причины междоусобиц и степень влияния на них международного фактора, а именно противостояния ведущих держав того времени - Российской и Османской империй - за сферы влияния в южных морях и в Кавказском регионе. В результате анализа исторических источников автор пришёл к выводу, что феодальные междоусобные войны дагестанских ханов во многом были спровоцированы действиями внешних игроков. Ареной противостояния стали приморские южные земли Дагестана и северные земли современного Азербайджана, населённые преимущественно этническими дагестанцами.

Ключевые слова: Российская империя, Османская империя, Южный Кавказ, Дагестан, Дербент, Кубинское ханство, Кайтагское уимийство, междоусобииа.

Восточный Кавказ до присоединения к Российской империи в XIX в. имел весьма пёстрое политическое устройство в силу своей полиэтничности и наличия множества феодальных владений и вольных обществ, чьи границы и политический вес периодически менялись в зависимости от конкретной военно-политической обстановки. Кроме того, значительное влияние на обстановку в регионе во все времена оказывали ведущие державы, которые проявляли пристальный интерес к нему, вследствие чего он всегда находился в состоянии перманентного конфликта и политической нестабильности.

В этом отношении не является исключением и XVIII век - один из самых сложных периодов, имевших судьбоносное значение для восточно-кавказских народов. Многократные вторжения правителя Ирана Надир-шаха Афшара в 1740-х гг. и усиление военного присутствия Российской империи в Западном Прикаспии во второй половине XVIII в. спровоцировали острый политический кризис, повлекший за собой междоусобицы среди дагестанских феодальных владетелей.

Целью данного исследования является изучение причин феодальной войны в Дагестане во второй половине XVIII в. и степени влияния на данный процесс внешнеполитического фактора.

Новизна представленной работы состоит в том, что история феодальной междоусобной войны в Дагестане во второй половине XVIII века в контексте борьбы мировых держав за влияние в данном регионе не изучалась. По рассматриваемой проблеме практически отсутствуют сколько-нибудь заметные научные исследования.

Следует отметить, что наиболее влиятельными феодальными владениями Дагестана в исследуемый период были Кайтагское уцмийство, Дербентское, Казикумухское и Аварское ханства, Тарковское шамхальство, а также федерация вольных аулов Центрального Дагестана - Акуша-Дарго [1, с. 49-52, 193-217, 245-255]. 
В период борьбы с Надир-шахом указанные феодальные владения, объединившись, вместе выступили против общего врага. Но уже при следующем поколении феодальных владетелей между ними начались острые разногласия, вызванные личными неприязненными отношениями между владетелями, их борьбой за влияние в регионе, а также расхождением во взглядах на военное присутствие Российской империи в Западном Прикаспии: одни владетели стремились под протекторат России, другие выступали против продвижения России на юг от Терека. Указанные факторы привели к военному конфликту между южнодагестанскими ханами, который является объектом нашего исследования.

Междоусобная война в Южном Дагестане фактически началась в период острого международного кризиса, вызванного обострением отношений между Российской и Османской империями и последовавшей в 1768-1784 гг. войной между ними. Противоречия между указанными ведущими державами того времени во многом стали причиной политических разногласий между дагестанскими ханами в связи с их разной политической ориентацией - Амир-Хамза Кайтагский и Мухаммад-хан Казикумухский выступали за союз с Османской империей, тогда как Фатали-хан Дербентский и Муртузали Тарковский стремились к укреплению отношений с Российской империей.

Отметим, что до 1768 г. указанные феодальные владетели были не просто в хороших отношениях: между ними существовал военно-политический союз, сформировавшийся в основном усилиями наиболее влиятельного из них - уцмия Амир-Хамзы Кайтагского. Кроме того, эти ханы состояли между собой в близком родстве благодаря династическим бракам [2].

В ходе междоусобной войны основная борьба развернулась вокруг Дербента, который во все времена имел важное экономическое, политическое и культурное значение для всего Восточного Кавказа. Тот, кто обладал им, по сути контролировал иакой стратегически важный регион, как Западный Прикаспий.

Важнейшим политическим игроком, способным напрямую влиять на решение вопроса о принадлежности Дербента, был его северный сосед, сильное феодальное владение - уцмийство Кайтагское (Хайдак), чья территория простиралась с запада на восток от Каспийского моря до подножий Главного Кавказского хребта и с севера на юг - от речки Гамриозень до Дербента соответственно [3, с. 215; 4, с. 309]. Правителем его в исследуемый период был уцмий Амир-Хамза.

Южным соседом Кайтага было владение правителя Дербента и Кубы Фатали-хана (1736-1798), который являлся двоюродным братом уцмия Амир-Хамзы (мать Фаталихана Пери-Джахан-бике была дочерью Ахмед-хана Кайтагского). Кроме того, сестра Амир-Хамзы Тути-бике была замужем за Фатали-ханом [5, с. 907].

По соседству с Дербентом и Кайтагом располагалось владение Табасаран, чей правитель Рустем-кади I был зятем Амир-Хамзы Кайтагского, будучи женат на его старшей сестре Бахтикай (ум. в 1756 г.). Уцмий Амир-Хамза, состоял в близком родстве и с аварским нуцалом Мухаммад-ханом IV (1730-1774), за которым была замужем другая его сестра - Баху. Сын Мухаммад-хана и Баху - знаменитый нуцал Умма-хан V Великий (1761-1801) был племянником уцмия Амир-Хамзы [6, с. 174-194].

До 1768 г. между Амир-Хамзой и Фатали-ханом имелись тесные союзнические отношения. В 1765 г. уцмий даже оказал владетелю Кубы военную и политическую помощь в войне против Дербентского эмира Гусейн-хана. Отряды Амир-Хамзы штурмом взяли северную стену Дербента, благодаря чему Фатали-хану удалось захватить город и присоединить его к своим владениям [7]. 
Безоблачные отношения между двоюродными братьями Амир-Хамзой Кайтагским и Фатали-ханом Дербентским резко испортились в 1767 г., очевидно, как было сказано выше, по причине русско-турецких противоречий, в которые оказались втянуты мусульманские феодальные владетели Кавказа.

Некоторые исследователи полагают, что причиной ухудшения отношений стал отказ Фатали-хана выдать свою сестру Хадидже-бике замуж за Амир-Хамзу [8, с. 131]. Однако внимательный анализ письменных источников, в первую очередь, донесений русских дипломатов и резидентов в столицу, позволяет считать, что причиной разногласий явилась прорусская ориентация Фатали-хана в обстановке назревающей русскотурецкой войны [9].

Известный исследователь русско-дагестанских отношений Ф.З. Феодаева отмечала, что турецкие власти прилагали значительные усилия для объединения мусульманских феодальных владетелей Кавказа против России [10, с. 185]. Фатали-хан Кубинский и Муртазали Тарковский ответили туркам категорическим отказом на предложение выступить против России, несмотря на щедрые дары от султана, о чём прямо говорит Фатали-хан в письме к Екатерине II: «Турецкий государь прислал ко мне несколько в город Каре посланцев с наилутчими арабскими лошадями, саблею, сайдаком, осыпанными дорогими лалатами, великою денежною казною и другими многими дарами, но я, искреннейший В. И. В. благополучия желатель... нимало не поколебавшись, присланных от турецкого государя до себя не допустя, отказал им в Карее и без всякого в желаниях успеха отослал обратно в Турецию» [11, с. 156]. Другие феодальные владетели Дагестана, судя по всему, приняли дары, поскольку позже они участвовали в войне против России на стороне Османской империи.

Фатали-хан, который, очевидно, был щедро вознаграждён российскими властями, настоятельно требовал от дагестанских ханов отказаться от поддержки Османской империи и встать на сторону России [12, с. 14]. Поэтому можно предположить, что его отказ выдать свою сестру за Амир-Хамзу являлся лишь следствием, а не причиной обострившегося конфликта. Реальная причина междоусобицы - принципиальные внешнеполитические разногласия.

Когда возник конфликт практически сразу же, уцмий Амир-Хамза захватил Дербент, изгнав кубинский гарнизон Фатали-хана, которому помогал четырьмя годами ранее захватить его. Фатали-хан тут же двинулся отвоёвывать город, с севера ему на помощь пришел другой пророссийски настроенный хан - шамхал Муртузали Тарковский. Ожесточённое сражение за Дербент продолжалось три дня, о чём сообщает Искандербек Гянджинский в сочинении «Жизнь Фатали-Хана Кубинского» [13, с. 36-37]. В разгар боевых действий за Дербент мирить племянников жены примчался нуцал Мухаммад-хан Аварский. Из работы Сереброва А.Г. «Историко-этнографическое описание Дагестана. 1796 г.» следует, что нуцалу Мухаммад-хану хоть и на время, но всё же удалось остановить войну между родственниками [6, с. 174-194].

Однако, несмотря на перемирие, с этого момента фактически складываются две непримиримые коалиции из антироссийски и пророссийски настроенных феодальных владетелей Южного Дагестана. В число первой вошли уцмий Амир-Хамза Кайтагский, Мухаммад-хан Казикумухский, Мухаммад-хан Аварский, Рустам-хан Табасаранский, Али-Солтан Дженгутайский, Баммат Казанищенский и Гусен-хан Шекинский. В пророссийски настроенную коалицию вошли Фатали-хан Кубинский, шамхал Муртузали Тарковский и майсум Шейхали-хан Табасаранский.

Междоусобица возобновилась практически сразу же после завершения русскотурецкой войны 1768-1774 гг. Победа в войне и заключение Кючук-Кайнаджирского 
мирного договора развязало руки правительству Екатерины II, которое приступило к реализации плана по усилению своего влияния на Кавказе. Обстоятельства складывались против уцмия Амир-Хамзы Кайтагского, который всегда придерживался антироссийских позиций. Правитель Кубы и Дербента Фатали-хан, напротив, чувствуя поддержку руководства России, стал вести себя ещё более агрессивно в отношении своих соседей, что привело в 1774 г. к возобновлению войны с Амир-Хамзой Кайтагским.

Ещё больше усугубила кризис череда трагических событий. Фатали-хан вторгся в соседнее Ширванское ханство, разбил небольшое войско его правителя Агаси-хана и присоединил его земли к своим владениям. Очевидно, это было сделано с одобрения руководства России, которое было не против ещё большего усиления позиций пророссийски настроенного феодального владетеля. Однако за Агаси-хана Ширванского заступился правитель Аварии нуцал Мухаммад-хан, который, как и Амир-Хамза, был противником усиления царской власти в Дагестане.

Произошёл ряд вооружённых столкновений, в результате которых Фатали-хан начал терпеть поражение. Поэтому, решив действовать иными методами, он предложил Мухаммад-хану переговоры, пригласил его в свой лагерь и предательски убил [7], несмотря на то, что аварский нуцал был мужем его тёти. Можно полагать, что это было сделано, чтобы услужить царским властям, которые были очень недовольны дерзким набегом Мухаммад-хана на Грузию, находившуюся под протекторатом России. Об этом пишет русский историк П.Г. Бутков, в начале XIX в. служивший на Кавказе в канцелярии главнокомандующего К.Ф. Кнорринга [14, с. 289].

Подлый поступок Фатали-хана вызвал крайнее возмущение Амир-Хамзы, который посчитал необходимым отомстить ему, и тем самым оказать помощь в кровной мести своему 13-летнему двоюродному брату Умма-хану, унаследовавшему власть в Аварском нуцальстве. Трагизм ситуации состоял ещё и в том, что смертельными врагами-кровниками стали трое двоюродных братьев, причём и Амир-Хамза, и Фаталихан, и Умма-хан были внуками Ахмед-хана Кайтагского.

Кульминацией кризиса стала битва между войсками Амир-Хамзы и Фатали-хана на Гавдушинском поле близ селения Худат, ныне Хачмазского района Республики Азербайджан, в октябре 1774 г. По сведениям русского майора А.Г. Сереброва, побывавшего в Дагестане спустя 20 лет после этих событий, Фатали-хан потерпел сокрушительное поражение: «Амир-Хамза разбил всех и гнал до лагеря Фат-Али-хана, видя гибель свою, войско от отчаянности разбежалось в разные места своей провинции. Сам Фат-Али-хан с малым числом чиновников своих убежал в свою ж провинцию в Сальяны» [1, с. 186]. Аналогичные сведения приводит А.-К. Бакиханов: «...Счастье клонилось сначала в сторону Фат-Али-хана, но Алибек, храбрый сын уцмия, так быстро ударил на центр неприятельских войск, что победа присоединилась к его мужеству» [8, c. 133].

В донесении русского резидента Василия Тарасова кизлярскому коменданту И.И. Штендеру сообщается, что у Фатали-хана было двукратное численное превосходство над Амир-Хамзой, 8 тыс. против 4 тыс. воинов соответственно. Но, несмотря на это, Амир-Хамза одержал уверенную победу: «Уцмий со своими согласниками (соратниками. - М.Г.), видя его превосходство, утвердил всех своих присягою, чтоб всем поступать бодрственно и, выстрелив по разу из ружей, идти на саблях (т. е. врукопашную. - М.Г.) с неустрашимостью, и ничего не брать, пока всех не разобьют. Таким образом, наперед и ударили на Фатали-ханово войско, кое удачно разбили, многих побили, других взяли в плен. Фатали-хан с малой частию ушел в Кубу...» [11, с. 153]. 
«...Отступая Фатали-хан не сумел удержать даже свою столицу Кубу, союзник Амир-Хамзы - Мухаммад-хан Казикумухский в результате молниеносной атаки захватил её...» [7; 15]. Сам уцмий в это время приступил к осаде северного форпоста владений Фатали-хана - крепости Дербент, в котором оборонялся достаточно сильный гарнизон.

В разгар битвы за Дербент в войну вступил другой феодальный владетель Дагестана, союзник Фатали-хана - шамхал Муртузали Тарковский, который со своим войском подошёл к северной границе владений Амир-Хамзы. Уцмий был вынужден снять осаду Дербента и выступить навстречу отряду шамхала. Судя по всему, Муртузали потерпел поражение, о чём говорит тот факт, что он отступил от границ уцмийства и практически сразу же обратился к России «с прошением и о вспомоществлении против хайдацкого уцмия и его сообщников» [7; 15], т. е. с просьбой о помощи и поддержке. Отогнав шамхала Муртузали от своих северных границ, Амир-Хамза возобновил осаду Дербента.

Что касается Фатали-хана, то, оказавшись на грани полного военного разгрома, ему, как и Муртузали Тарковскому, ничего не оставалось, кроме как настоятельно просить Санкт-Петербург о помощи и покровительстве [7]. В письме императрице Екатерине II он достаточно ясно намекал, что в случае отказа российских властей от военной поддержки в борьбе против Амир-Хамзы, он примет предложение правителя Ирана Керим-хана о помощи и покровительстве [11, с. 157].

Российские власти не могли допустить потери столь важного союзника, и, как справедливо отмечает дагестанский исследователь А.О. Муртазаев, полагая, что «окончательный разгром сторонника России нанесет ущерб интересам России в этом регионе» [7], решили вмешаться в междоусобный конфликт дагестанских ханов. От АмирХамзы в ультимативной форме потребовали отвести войска от Дербента. Уцмий, понимая, что его иррегулярные войска, измотанные в кровопролитных сражениях с Фаталиханом, не смогут противостоять русским, если они придут из Кизляра, был вынужден согласиться на требования и отвести войска. При этом он потребовал, чтобы Фаталихан отказался от претензий на Южный Табасаран, т. е. на Майсумство.

Следует отметить, что Табасаранское майсумство имело важнейшее значение для всего региона - его выгодное географическое положение позволяло держать под контролем очень важные с политической, экономической и военной точки зрения дороги из Кубы в Дербент и с гор на равнину. Поэтому стороны не достигли компромиссного решения. Амир-Хамза прямо заявлял, что в случае утверждения владетелем майсумства ставленника Фатали-хана убьёт его, как только русские войска вернутся в Кизляр. Поэтому майор Фромгольт в своём рапорте командующему войсками И.Ф. де Медему докладывал, что «желаемого здесь спокойствия никогда быть не может, ибо уцмий и кади, хотя и дали свою подписку в том, чтоб хану (Фатали-хану. - М.Г.) ничего не делать, однако сие показывают они по одной наружности...» [11, с. 162].

Действительно, не прошло и месяца после переговоров, как уцмий Амир-Хамза предпринял военный поход против Фатали-хана. Перед этим, оправдываясь, он написал кизлярскому коменданту И.И. Штендеру письмо, в котором обвинил Фатали-хана «в нежелании сохранять мир» $[11$, с. 163]. Фатали-хан и на этот раз потерпел поражение от уцмия и был вынужден запросить мира у него. При этом, как следует из донесения мурзы Астраханского войска Я. Джанбулатова кизлярскому коменданту И.Д. Заметаеву, он был вынужден пойти на значительные уступки уцмию, в том числе уступить право взимания дани с г. Шемахи, являвшегося одним из торговых центров всего Кавказа [11, c. 163]. 
В заключение следует отметить, что во второй половине XVIII века феодальные владения Дагестана оказались втянуты в геополитическое противостояние ведущих держав того времени - Российской и Османской империй. Личные амбиции наиболее крупных феодальных владетелей и их неспособность выработать единую внешнеполитическую позицию привели к трагическим событиям, а именно к кровавой междоусобной войне. И лишь победа России в войне над Османской империей и усиление её позиций в Кавказском регионе, позволили остановить конфликт. В это же время благодаря строительству опорных пунктов [16] и формированию северокавказского фронтира начинается активное продвижение и утверждение в регионе Российской империи.

\section{Литература}

1. Алиев Б.Г., Умаханов М.-С.К. Историческая география Дагестана XVII - нач. XIX в. - Махачкала, 1999. - 366 с.

2. Гаджимурадов M.T. Внешнеполитическая деятельность уцмия Амир-Хамзы Кайтагского в условиях утверждения российской власти на Восточном Кавказе во второй половине XVIII века // Манускрипт. - 2018. - № 12-2 (98). - С. 210-214.

3. Ахвердов А.И. Описание Дагестана. 1904 г. // История, география и этнография Дагестана XVIII-XIX вв. Архивные материалы / под ред. М.О. Косвена и X.-М. Хашаева. - М., 1958. -367 с.

4. Броневский С.М. Новейшие географические и исторические известия о Кавказе. Ч. 2. - М., 1823 // Электронная энциклопедия и библиотека Руниверс. Режим доступа: https://www.runivers.ru/lib/book3109/9781/

5. Акты, собранные Кавказской археографической комиссией / под общ. ред. А.Д. Берже. - Тифлис, 1875. Т. VI, ч. II // Государственная публичная историческая библиотека. Режим доступа: http://elib.shpl.ru/ru/nodes/1761-t-6-ch-2-1816-1827-1875

6. Серебров А.Г. Историко-этнографическое описание Дагестана. 1796 г. // История, география и этнография Дагестана XVIII-XIX вв. Архивные материалы. - М., 1958. - 367 c. // Library.ru: информационно-справочный портал. Режим доступа: http://www.vostlit.info/Texts/Dokumenty/Kavkaz/XVIII/1780-1800/Serebrov_A_G/opisanie _dagestana_1796.htm

7. Муртазаев А.О. Особенности взаимоотношений дагестанских владетелей в 5080-х гг. XVIII в. // Вестник Института истории, археологии и этнографии. - 2008. № 14. - C. 16-33.

8. Бакиханов А.-К.-А. Гюлистан-и Ирам. - Баку: Элм, 1991. - 304 с.

9. ЦГА РД. Ф. № 379. ОП. 2. Д. 3124. Л. 65.

10. Феодаева Ф.3. Русско-дагестанские отношения во второй половине XVIII начале XIX в. - М., 2008. - 293 с.

11. Русско-дагестанские отношения в XVIII - начале XIX в.: сборник документов / отв. ред. В.Г. Гаджиев. - М., 1988. - 356 с.

12. Маркова О.П. Россия, Закавказье и международные отношения в XVIII в. - M., 1966. $-322 \mathrm{c}$. $54 \mathrm{c}$.

13. Гаджинский Искендер-бек. Жизнь Фатали-хана Кубинского. - Баку, 1959. -

14. Бутков П.Г. Материалы для новой истории Кавказа, с 1722 по 1803 год. СПб., 1869. - 548 с.

15. Рапорт ротмистра Терского войска в Кизлярскую комендантскую канцелярию // ЦГА РД. Ф. 379. ОП. 1. Д. 556. 
16. Гарунова Н.Н. К вопросу о дате основания крепости Кизляр в XVIII в. // Известия Волгоградского государственного педагогического университета. - 2018. - № 3 (126). - C. 176-180.

Поступила в редакиию Іиюля 2019 г.

DOI: $10.21779 / 2542-0313-2019-34-2-14-20$

\section{Feudal war in South Dagestan in the second half of the XVIII century}

\section{M.T. Gadzhimuradov}

Dagestan State University; Russia, 367001, Makhachkala, M. Gadzhiev st., 43a; murad-docent@mail.ru

The article is devoted to the study of the problem of feudal internecine wars in Dagestan in the second half of the 18th century. The causes of civil strife and the degree of influence of the international factor on them are analyzed, to be exact - the confrontation between the leading powers of that time - the Russian and Ottoman empires - over the spheres of influence in the southern seas and in the Caucasus region. As a result of the analysis of historical sources, the author came to the conclusion that feudal internecine wars of the Dagestan khans were largely provoked by the actions of external players. The arena of confrontation was the coastal southern lands of Dagestan and the northern lands of modern Azerbaijan, inhabited mainly by ethnic Dagestanis.

Keywords: Russian empire, Ottoman Empire, South Caucasus, Dagestan, Derbent, Quba Khanate, Kaitag Utsmii,Civil strife.

Received 1 July, 2019 